\title{
RESET
}

Recherches en sciences sociales sur Internet

\section{Self-Injury and the Internet}

Reconfiguring the Therapeutic Community

Automutilation et Internet: Les reconfigurations des communautés

thérapeutiques

Patricia A. Adler and Peter Adler

\section{OpenEdition}

\section{Journals}

Electronic version

URL: http://journals.openedition.org/reset/310

DOI: $10.4000 /$ reset.310

ISSN: 2264-6221

Publisher

Association Recherches en sciences sociales sur Internet

\section{Electronic reference}

Patricia A. Adler and Peter Adler, « Self-Injury and the Internet », RESET [Online], 2 | 2013, Online since 01 July 2013, connection on 09 October 2020. URL : http://journals.openedition.org/reset/310 ; DOI : https://doi.org/10.4000/reset.310

This text was automatically generated on 9 October 2020 .

(c) Association Recherches en sciences sociales sur Internet 


\title{
Self-Injury and the Internet
}

\author{
Reconfiguring the Therapeutic Community \\ Automutilation et Internet: Les reconfigurations des communautés \\ thérapeutiques
}

Patricia A. Adler and Peter Adler

\section{Introduction}

1 Long a subterranean topic, the deliberate, non-suicidal destruction of one's own body tissue emerged from obscurity in the 1990s and began to spread dramatically. Selfinjury has gone by several names, although self-harm and self-mutilation have been the other most common appellations ${ }^{1}$. Although a range of behaviors may be considered self-injurious, including eating disorders, excessive laxative use, and extreme body modification, among others, we focus here on those specific behaviors that have been identified by the psychiatric and medical communities as falling into this specific syndrome: self-cutting, burning, branding, scratching, picking at skin or re-opening wounds, biting, head-banging, hair-pulling (trichotillomania), hitting (with a hammer or other object), and bone-breaking.

2 Most discussions of self-injury have traditionally derived from within the parameters of the psychological and treatment professions, which classify it as a symptom of several other disorders, most notably those having to do with impulse control. Lodged primarily within the "dramatic-emotional" dimension, self-injury is viewed as environmentally rather than organically caused, and rooted in psychological or situational problems incurred during people's maladaptive childhoods. As such, it is considered an occasional side-effect of borderline personality disorder (BPD: inappropriate anger, impulsive self-harming behavior, and extreme sensitivity to stress) ${ }^{2}$, antisocial personality disorder (the tendency to be aggressive, to have reckless disregard for personal safety), histrionic personality disorder (a pervasive pattern of excessive emotionality and attention-seeking behavior often enacted through physical appearance), post-traumatic stress disorder (sometimes due to rape or war), various 
dissociative disorders (including multiple personality disorder), eating disorders ${ }^{3}$, and a range of other conditions such as kleptomania, Addison's disease, depersonalization, substance abuse (Joiner, 2005), alcohol dependence, and assorted depressive disorders ${ }^{4}$.

Previous models of therapeutic treatment for self-injury have largely been focused on individualistic psycho-medical approaches that isolate and stigmatize people who cut, burn, and otherwise self-harm. In fact, prior to the mid-1990s, when self-injury began to emerge from obscurity through celebrity admissions ${ }^{5}$, heavy metal onstage displays ${ }^{6}$, and a few early magazine articles and movie/television portrayals ${ }^{7}$, people discovered or who admitted to self-injuring were commonly whisked off to the psych wards of mental hospitals and involuntarily committed for a month or more. But as self-injury increasingly emerged from obscurity in the subsequent decade, knowledge about the behavior spread dramatically, as did its prevalence.

4 The self-help/mutual aid movement, beginning with Alcoholics Anonymous (AA) in 1935, grew by the 1980s and 1990s to encompass a tremendous proliferation of peer support groups (Kurtz, 1997). These were not psychiatric groups, led by a therapist in either inpatient or outpatient settings, but user-led support groups, unstratified in their membership positions, and fueled by the experiences of uncredentialed individuals who congregated to help themselves and help others (c.f. Harwood, 2010; Kurtz, 1997). Such groups are premised on the idea that people who share a common behavior they view as undesirable can collectively aid each other through their direct experiences and personal insight. In 1970, Lyman suggested that user-led support groups within which deviants congregate may have two dimensions, expressive and instrumental, enabling them to nurture and expressively support members within a backstage gathering of like others and/or to instrumentally draw on their organizational effectiveness to lobby, protest, or otherwise work toward the goal of changing societal definitions, beliefs, or values. By 1993, it was estimated that American self-help group membership had risen to 6,000,000, with exponentially higher figures world-wide (Moos et al., 1993). Yet for some types of behaviors, notably the most stigmatized, face-to-face, or solid world groups did not arise ${ }^{8}$.

One of the most significant developments for the evolution of self-injury can be found in the rise of the Internet. Computer use has grown exponentially in the 2000s, with over $70 \%$ of American adults using the Internet regularly, $65 \%$ of them going online daily (Lenhart, Madden \& Hitlin, 2005). By 2008, $75 \%$ of American women and $73 \%$ of men had access to computers and were venturing into cyberspace (Pew, 2008). $80 \%$ of those use the Internet to seek information about health issues, with $22 \%$ of them looking up information about mental health (Fox, 2006). Online mental health support groups have become as prevalent as face-to-face peer support groups, with Yahoo! Groups hosting nearly 19,000 support groups for diseases and health conditions, 3,700 of those focusing on mental health (Kaplan et al., 2011).

6 Self-injury communities (Websites, listservs, blogs, and bulletin boards) began to appear on the Internet sometime around in the early 2000s, some hosting chat rooms, where people could interact with fellow and former self-injurers, with those who wished to discourage the practice, and with random other visitors. In 2005, a scan of the Internet revealed over 400 self-injury cyber-sites, by 2006 the number had increased to over 500 (Whitlock, Lader \& Conterio, 2006), and it has continued to grow ever since. 
$7 \quad$ Yet it is unclear what effect these cyber self-injury sites have on their users. Eysenbach et al. (2004) suggested that little is known regarding the health and social effects of Internet-based support groups. Drawing upon a base of over 135 face-to-face and telephone in-depth life history interviews with self-injurers located all over the world and tens of thousands of Internet messages and emails including those posted publicly and those written to and by us between 2000 and 2010, we describe some of the ways our subjects interacted over the Internet and the effects this had on their individual and collective behavior. We begin by discussing our methods and then address the connections members forged with their groups. We document the evolution of selfinjury sites on the Internet over the first decade of the twenty-first century and the way these changes differently affected participants. We examine the dynamics of these groups, their functions for members, and their effects on self-injurious behavior. We conclude by looking at effects of these groups on members' behavior, self-concepts, and interaction within society through both normalization and moral passage.

\section{Methods}

8 The nascent idea for this research began in 1982 when a student of Peter's spoke to him about her cutting. Over time we continued to meet people who cut themselves, which eventually expanded to include burners, branders, and bone-breakers. Becoming curious about the nature of this behavior and its spread, in 1999 we began the process of applying for IRB ${ }^{9}$ clearance to conduct research on the topic. It took two years to obtain that permission, and there were extensive precautions and safeguards, updated yearly, that we had to follow in gathering data from this vulnerable population.

This analysis draws on more than 135 in-depth interviews, conducted in person and on the telephone. Participants ranged in age from 16 to their mid-fifties, with more women than men, nearly all Caucasian. Due to the extremely sensitive nature of this topic and the gendered nature of participants, Patti took the lead role in gathering data. In searching for subjects, we began with a convenience sample of individuals who heard, on one of our campuses, through radio interviews, or through the grapevine, that we wanted to talk with people who self-injured. We required those who were interested to contact us via email, preview the consent form on our Website, and ask for an appointment. These interviews were conducted in our campus offices or at private places chosen by our subjects. Much to our surprise, dozens of volunteers stepped forward to be included in the study.

In addition, in 2001-02 we began to explore the Websites and public postings of selfinjurers. We joined several Internet self-injury groups as overt researchers and became active participants in group discussions. Because of the intimate nature of virtual communication (Chen, Hall \& Johns 2003; King, 1996; Mann \& Stewart 2000), we formed several deep and enduring relationships with people in different friendship circles that lasted over years, discussing with people the features of their ordinary lives and rallying around them during their many crises. We worked, with others, on the difficulties of supporting people who were disembodied and distant. Together with them, we learned to discern the seriousness of people's suicidal threats, their claims of abstinence, their presentation of different personas under different pseudonyms in different groups, and the consequences of flame wars. We networked through bulletin boards, MySpace, and the hundreds of self-injury related Web Usenet support groups. 
11 We collected thousands of Internet communiqués and emails including those posted publicly and those written to and by us. For this endeavor, we primarily used our Internet connections, like other cyber-researchers (Chen, Hall \& Johns 2003; King, 1996; Mann \& Stewart, 2000; Waskul, 2003, 2004; Waskul \& Douglass, 1996), as a means of recruiting subjects. The telephone interviews we obtained through these channels ranged in location all over the United States, Canada, and Great Britain. Of the more than 135 interviews we completed, 77 were with people who used the Internet in connection with their self-injury.

These interviews were unusually emotional and intense, lasting anywhere from one to four hours. Although some people were initially concerned about being judged by an outsider, the topic's intimate nature and our value-neutral stance led to the establishment of fairly deep rapport rather quickly. People began by telling the story of how they grew up, what their family lives were like, and how they discovered selfinjury. Since much writing has associated self-injury with some past trauma, we were especially careful when probing about such events. Most people discussed their past verbal, physical, or sexual abuse, some traced their current emotional distress/pain to the relatively common traumas of adolescence such as peer rejection or parental/ sibling favoritism, but others insisted that their childhoods had been basically happy. Over a dozen of these people have remained in contact with us, continuing to share their evolving ideas and life experiences. We have counseled these individuals on their educations, romantic involvements, parental relations, job searches, and traumatic experiences.

Following this natural history approach, the interviews then moved to specific concepts that evolved inductively over the course of the project (Becker \& Geer, 1960). At the end of the interview, Patti asked each subject what made him or her volunteer to come forward. Nearly everyone said the same thing: they wanted others who selfinjured to know that they were neither alone nor crazy, and they thought that, by sharing their experiences with us, we would write something that would shed light about self-injury for others.

Epistemologically, these conversations, relationships, and interviews are grounded in the value neutrality of the interpretive, Weberian tradition of the Chicago School. Rather than remaining strictly detached from our subjects, we became involved in their lives, helping them and giving voice to their experiences and beliefs, considered by some postmodern ethnographers and liberal feminists a form of advocacy. Yet radical feminists view self-injury as violence against women and regard people who speak about it non-judgmentally (even in giving voice to others) as supporting the hegemonic order of patriarchal oppression (Jeffreys, 2000). To the extent that we present our subjects' perspectives, our value neutrality is seen, then, as a moral relativism that ignores the inherently oppressive nature of self-mutilation. On the contrary, we maintain that we are giving power to people who have been mostly unheard and misunderstood.

\section{Support in an Online Community}

15 Not all self-injurers ventured online. Out of the people who contacted us requesting face-to-face interviews (not all of whose requests we granted due to data saturation), only a very small percentage (less than $3 \%$ ) reported going to the Internet to look for 
information or to seek out others. The online self-injury population undoubtedly represents a selective sample of those who engage in the behavior and, as our small population suggests, most of these people were those more seriously involved with the practice.

The rise of the Internet, at the turn of the twenty-first century, occurred at approximately the same time as self-injury was evolving into a more widespread and popular phenomenon that took on new social meanings and modes of practice. As a result, they developed together, in tandem.

\section{Evolution of Cyber Communities}

Cyber self-injury sites ranged in their orientation and regulation, from those that were single-issue to multi-issue, from those that were tightly to loosely controlled, and from those that condemned the practice to those that embraced it.

In the early 2000s, many of the places people found by Googling words like selfmutilation, self-harm, or self-injury took them to Websites, diaries, groups, and bulletin boards that were largely unregulated, allowing explicit discussion or postings about people's injuries. These sites were very permissive in the subjects participants were allowed to discuss, the language used, the level of venting that was allowed, the tenor of interaction on the site, the reliability of how people presented themselves, and the composition of participants or members. Often, newcomers wandered into these sites without fully realizing their nature. A short exchange, from 2004, shows this kind of misunderstanding and its correction:

Lildevil: I'm leaving thats it I quit there is no one there to help me any more.

Freedomfire [listowner]: Help you? This is not a help community ${ }^{10}$.

Some groups or sites were unregulated due to a lack of oversight from the original creators. Another brief set of exchanges from 2004 shows the kind of interaction that was typical at an unregulated site:
Shardsforlife: I am not very good at this due to my razor being a piece of shit and my camera crapping out.. anywho here are some pictures of a few cuts that i did about 3 hours ago when my boyfriend, or ex, decided he was gonna be a dick and break up with me.. [4 pictures]
Artfag: I know what under boob cuts feel like: they don't hurt at all. or maybe i've just built a tolerance. oh well. kinda light cuts :।
Denada: hmm I'll have to agree with you on this one, they are light cuts, but if that's her thing then that's her thing! I'll post some of my pictures when they are finally developed!
Riphertoshreds: I don't want to post negatively here, but those are kinda light cuts...did you use a pin/nail or something?

This accepting attitude toward injuring and posting vivid pictures of cuts that were still bleeding clearly encouraged people to cut and to display their own accomplishments. At the same time, the judgmentalism about what others said was accompanied by a competition that pushed individuals to engage in more severe self-injury.

Unregulated sites could also be those that accepted members' relationships with their self-injury. Some of these sites were very explicit in their avowedly pro-self-injury orientation. These approached self-injury in much the same way as the pro-Ana and pro-suicide movements ${ }^{11}$, treating it as a voluntary lifestyle choice and a long-term coping mechanism. Considering individuals' decision to injure themselves rather than 
injuring others constructive, they encouraged people to help themselves embrace their self-injury and, like others in a tertiary deviant stage (Kitsuse, 1980), to shed the stigma. Along with this they offered practical suggestions for engaging in self-injury, managing relationships with friends and family members, and dealing with the physical problems this generally engendered. Zoe, a member of an early unregulated group, posted the following view of self-injury:

I honestly don't see what is so wrong with cutting. I think Im kinda looking to see if anyone agrees. I mean, instead of punching a pillow, you just take it out on yourself. As long as you dont do it too deep, whats the big deal??? It's better than abusing the people around you. The real problem with it is the emotions and the depression BEHIND the cutting, right? If it isnt "adversely affecting one's life," as is required for anything to be a legal disorder, then why does everyone else think it is wrong... Am I making any sense to anyone???

She received the following response from Angie:

Hi there!! Nice to hear from you, welcome! As I was reading your posts, I couldn't help but feel as tho I was reading something that I had written!!! I don't see too much wrong with it either, it doesn't hurt anyone but myself.

But "flame wars" (eruptions of open hostility) and tacit encouragement of self-injury eventually drove many people to seek safer havens, whittling the population in these sites to a smaller, more hard-core group. As a result, beginning in the mid-2000s unregulated sites started to decline in popularity. Participants visited them less often and servers that hosted them took steps to shut them down. Many were driven underground, only to resurface under different names on different servers, forcing users to engage in a frequent search for new cyber-locations.

In their place, highly regulated groups sprang up that sought to protect people from excessive triggering and competition, and a regulatory structure evolved, complete with moderators assisting listowners in screening postings. One group had a firm nononsense policy, as one of the moderators posted:

The reason that this group exists is to help people in recovery. All members are asked to identify the alternatives s/he tried to use to avoid using SI as a coping mechanism. For those who are not ready to embrace recovery, this is the wrong group.

Moderators and members accepted people's slips into self-injury as long as they only discussed their feelings about it and not their injurious acts, and as long as they remained staunchly committed to quitting. Their rules not only prohibited discussions of individuals' self-injury, but also any use of the actual terms. Any email that the author could construe as having the possibility of upsetting others had to have the word "trigger" in the title so that people could avoid reading it.

This type of forum appealed to people who were very fragile and easily susceptible to others' descriptions of their urges or acts, or to people who couldn't handle conflict on the site. Certain words were banned entirely, while others were replaced with initials or euphemisms (i.e., SA for sexual assault, ED for eating disorders, SI for self-injury). Sets of rules were regularly posted reminding participants of the boundaries. When problems arose, members were likely to appeal to owners or moderators, either privately or through the group forum, to censure recalcitrant individuals. This kind of control gave greater feelings of safety to sensitive individuals. At the same time, it blocked the expression of various types of discussion that some people wanted or needed. 
sites were more moderate in their orientation and regulation. By the mid-2000s, most sites had moved into this category, offering a broader orientation towards selfinjury and supervision; this served to mediate interaction but did not stifle communication. These ranged from sites that were generally recovery oriented to others that accepted posts that were somewhat but not too venting. People flocked to these who found the unregulated groups too triggering. They had everything, from people who loved cutting, to those that were ambivalent about their self-injury, to those who had quit. If people wanted to stop, there were those who would support them. If people wanted to continue, others would accept them. Penelope was a 20-yearold college student who also worked as a graphic designer. She indicated that the mild orientation of the group toward recovery was particularly important to her, noting that, "I was looking for people who hurt themselves who weren't so focused on stopping it because I didn't know that I could stop it at that point."

Tasha, a 21-year-old teacher's assistant, said that she felt comfortable in her community because the moderators read and approved most of the postings before they went online. She chose this group after trying out a few others because this previewing cut down on people telling "crazy stories that were usually not true" and people yelling or cursing at each other. Yet, as one new member made sure to initially ascertain, people could still discuss their troubles:

Hello my name is Sheila and I am not new but I've been in a hospital for the past 2 weeks. I was trying to work up the courage to talk to people about it but I've already been deleted from one group and would not like to be deleted from anymore. i need people to talk to, do I still have your support?

\section{Functions of Cyber Communities}

Self-injury cyber communities served several functions for members in all of these various types of groups.

\section{Identification with the Community}

Although people often belonged to various sites and sometimes went for long periods between postings, when they found a community that fit them well, they identified with it. They experienced this whether they were actively self-injuring or not. Jones (1997) noted that people's sense of identity is not only derived from identification with the group, but from their understanding of the group identity. Erica was an 18-year-old college freshman who was sexually abused by her brother at seven. By age 12 she was trying a range of different injurious behaviors, progressing from scratching herself to using paper clips to using toothpicks, keys, safety pins, scissors, exacto knives, blades, and knife sharpeners to cut herself. She even slammed her hand in a heavy metal door on several occasions to break her bones. She discussed with us the importance to her of finding a community where there were other people who had been through things similar to herself:

You've been there; you know what it's like. I have traits in common with other members of the community: being sexually abused, being a perfectionist, having an ED. Always like, trying to help other people, doing community service, volunteer work, I'm really into that. Like everything they say on those Websites is completely 
me. I don't think it's all cutters; I think it's the majority of cutters. I just happen to

fit. So it makes me feel more connected to the community as a member.

31 encountered, whether they had fully functioning work and social lives and hid their self-injury, or if they were trapped in their houses or bedrooms, unable to make contacts with people in the solid world. McKenna and Bargh (1998) suggested that people with concealable stigmas identify more strongly with these Internet support groups and consider them more important to their identities. As a result, they are also more likely to achieve greater self-acceptance, decreased estrangement from society, and decreased social isolation. Deshotels and Forsyth (2007) proposed that identities forged with the aid of Internet groups may help people disengage themselves from normative social control.

\section{Forging Identities as Self-Injurers}

A natural outgrowth of identifying with a community was that the collective identity of the group transferred to its individual members, leading people to develop stronger identities as self-injurers. In our interviews, we noted clear differences in the way people who belonged to cyber communities self-identified as injurers compared to those who eschewed these groups. This could be partly due to a self-selection factor, since people who injured more and felt this was a central part of themselves were more likely to look online for a support group. Yet we found that their cyber interactions advanced this aspect of their selves further. People we interviewed in person who did not have cyber support were apt to accept the behavior, but reject the identity. For example, Gwen expressed this by saying that it was "...part of me but not the whole of me, not even the main part." Kelli, with a history of sexual abuse and eating disorders, regarded it as, “....a temptation I still have to resist, but I don't think it is my master status or anything. Like, I am not a cutter, but I am a person who has cut."

Lemert (1967) discussed how primary deviants, who keep their deviance hidden from others, have the luxury of denying self-identification with their behavior. Becker (1963) expressed this theme as well, arguing that "secret deviants" are unlikely to conceive of themselves through the deviant lens. Nicola, a college freshman, knew a cutter who flaunted his injuries. She distinguished herself from him by explaining that, "No one ever really found out, thus I was never labeled. I never saw it as part of my identity."

In contrast, people who joined online communities revealed their behavior to others. Bonnie, a 33-year-old bankruptcy coordinator, said that this felt like a significant coming out in her life, even though she knew she would never see these people face-toface. Erica, who had broken bones by slamming her hand in a door, discussed how going to the Internet changed the way she thought of herself:

Q: At this point did you identify yourself, any part of your identity, as connected to that behavior?

A: No. Actually I always just thought I wasn't actually a cutter, I was just utilizing it. Q: That's interesting. Tell me how you see the difference.

A: I guess I thought cutters couldn't control themselves. And I thought I had major control, which I didn't. I just thought cutters are addicted; I'm not. Cutters always need to cut; I don't. I just do it for fun, which really wasn't true actually, at all. Q: When was it that you started to identify more with being a cutter?

A: I'd say my sophomore/junior year [of high school].

Q: And what made the difference that you embraced that more as an identity?

RESET, 2 | 2013 
A: I think just the fact that during my sophomore year I was like looking on the Internet, looking at stuff, reading about it. Everything was just like, you're not alone.

Q: Tell me what about this site helped you change your identity, to incorporate that more into it?

A: Just the fact that there were other people doing it. Maybe, like, there's a group of people. I am part of this group, obviously. That helped me connect my identity to a self-abuser. Whereas before I was just like, one of two people doing it, so it wasn't really an identity, it was more of a habit. Whereas on the Internet it's a lifestyle, almost.

Tasha, a 24-year-old first grade teacher's assistant, agreed with this sentiment, noting she had gone for many years viewing her injury as a private thing that was not a problem. She knew that it wasn't a good thing, but since it worked "really well" for her she kept quiet and compartmentalized it to herself as just something she did. Even as she took psychology classes in college and read things that touched on self-injury, she never told any friends about it, fundamentally refusing to deal with it. For her, joining her community signified an admission that her self-injury was real, was a problem, and had to be addressed.

Jimmy, a 19-year-old Alaskan college student, noted that registering to join a group meant acknowledging that his self-injury was not a quick passing thing, but something with which he was dealing. Diana, a 44-year-old Swedish woman on disability, said that it caused her to feel a change because she was part of a group of people who would understand what she was talking about. Darcy, a 19-year-old college student whose parents had gone through an ugly divorce, added that spending hours daily interacting with other self-injurers online increased the likelihood of people identifying with the behavior.

\section{Helping Themselves by Helping Others}

A critical function that people sought in going online was to help themselves by helping others, what Riessman (1965) has called the "helper-therapy principle." As Brown (1991) noted in his study of alcohol and drug counselors, many people who had been through drug and alcohol problems turned during their early stages of sobriety to counseling other drug addicts and alcoholics. They went through the training to get professionally certified and worked in the field helping others. In this way they capitalized on their former deviance to build a new occupational avenue, becoming what he called a "professional -ex." A side benefit of the time they spent in this pastime was that being in the setting reinforced their abstinence. Thus, by helping others, they also helped themselves.

Many self-injurers posted to sites about their desire to help others and expressed this sentiment strongly to us as well. Assisting others gave them a sense of value and purpose when their lives were feeling tenuous. They wanted to be there for others as people had been for them. They deeply believed that they were best equipped to understand and to give advice to self-injurers, that their words would have greater resonance to other practitioners because of their own struggles. At the same time, they hoped that by motivating others, they would strengthen their own resolve. We see this well-articulated by Sally's post and her response to a query:

Sally: Hi there, my name is Sally and I am a former cutter. I have not cut in over 4 years now after cutting for 7 years and I would to like to help others out there who 
need someone to talk to who understands what they are going through. I know how hard it is to find people who actually understand what is going on in our head when we do this stuff. Please e-mail [address]

Becca: Have you helped anyone else Sally? Are you sure it wouldn't trigger you to do it again?

Sally: In the last two years, I have helped 6 young women and one young man to understand what they are doing with themselves and to be there and mentor them. If anything, the experience has helped me to not want to cut even more. As I look into the eyes of these people with such bright important roles to play in the future, I realize that I to was one of them. That is why I am here, to help others on here who might need help getting through what I got through. There is hope and people who understand. If I made it through, and can help others, than I am sure that others can too.

\section{Normalization} dangerous, suicidal, or crazy. It gave them the social support of others with similar experiences who could relate to them intimately about their frustrations and pain, their sadness and stress, and their cycle of troubled interactions and relationships. It gave them an audience to whom they could turn, at any time, and get a sympathetic response. Even close friends or family members, in whom they had confided about their self-injury, could not be there for them in this way, as Danielle, a 35-year-old Florida housewife and mother of three, noted:

I've told my husband about my injuring, and one of my closest friends, but I can't go to them on a daily basis to talk about my urges, my feelings. Things stress me out more easily than most people and I have a hard time recovering my equilibrium, so they get tired of listening to me and being sympathetic. So I feel guilty burdening them, and I have to save it up. On [message board], everyone is in the same situation. They'll listen forever and be interested forever, because they need to vent and get help in the same way. I'm much more accepted there with all of my warts.

Isolated self-injurers were also ignorant about many things that they sought information about online. Many from religious backgrounds and communities grappled with the stigma of being labeled sinful by their families and communities. Online friends refuted the views that self-injurers were morally unworthy because they lacked the willpower to stop the behavior, that they were committing a sin against their bodies, God, or the church, or that they were driven to self-injury by evil religious forces. References to God and religion could be found on self-injury sites, but most of these were positive. People reassured others that they weren't inherently evil, or that they could look to God for redemption.

When people attempted to preach at fellow self-injurers, they were often chastised by others. Some sites rejected membership applications from inveterate preachers, or evicted them after members complained. Members reinforced others' inherent goodness, and re-cast their injurious behavior as a problem that they could overcome, not a reflection of some inner stain or moral weakness.

RESET, 2 | 2013 
way online sites collectively counteracted the stigma of sin was to cast self-injury as a sickness. Many advanced the view that their self-injury was addictive, or beyond their control. Online psycho-medical discussions were common, focusing on people's psychiatric diagnoses, therapy, hospitalizations, and struggles with medications. Someone posted to a Website saying, "A psychiatrist once told me that because of the extreme chemical imbalance in my brain that I would probably always fight with suicidal impulses and SI, even with medication. He said there was no way to fight those for me." Those who acquiesced to the medical paradigm tended to have a fairly passive view of their own agency in struggling with their self-injury, as one posting to a group illustrated:

Do you or do you know shome one that has an addiction? It is the same as smoking/ drinking/stealing/lying/SI.... no matter what it is, if you feel that you cannot live without doing it/ have to do it. Then it is an addiction, not so much a choice. I have been SI for 6 years, going on 7. I have been this way since I was 13 years old. This is the only way I know how to cope. Sometimes I have to do it even though I do not want to...I really cannot explain the feelings... but something inside tells me that I have to, I have no choice in the matter so then it begins again, the cycle of SI. And breaks my record. I do not SI because I choose to, I do it because I have to.

The medical model of self-injury removed the stigma of sin and moral failing from individuals, casting them as patients who were sick and needed help. In turning to the medical establishment, they embraced the commonly held view in society that they could be helped by therapy and drugs. Yet many found that these solutions were often problematic, and so they turned to others on their sites for help with their frustrations with the medical community. They vented about their therapists, their diagnoses, their medications, their treatment in hospitals, and their insurance. Online, they found a willing community of others with similarly bad experiences who could validate their conclusions. This helped them to forge new, collective definitions of the medical establishment's diagnoses and treatments as wrong.

The third way self-injury cyber-communities normalized the behavior was to define it as selected, or a voluntary choice. In contrast to the sin and sickness ideologies, the selected model advocated that self-injurers controlled their own volition and made conscious decisions to practice this behavior. Vanessa, a 20-year-old college sophomore, conveyed her rejection of the medical model:

Like the Today Show was doing this "seven-part series," which is so beating a dead horse, on self-injury and they bring all these teenagers that are like, "I had a problem." And they're bringing all these psychiatrists and they're like, "These kids, they need help; it's a mental disorder." I was like, "That is so not it." It's just, it's a personal way of expressing emotion; it is a lifestyle choice; it's just the way you choose to express your emotions. I mean everybody has to have an outlet. You can go and do martial arts as your expression or you can do art, or you can cut yourself. If some people do it as a problem, if a cutter views it as a problem, then yes, they should get help because if they view it as a problem, then it is a problem. I never saw it as a problem. I just saw it as the way that I chose to do it.

Someone posting to a self-injury group asserted her rejection of the addiction model as well, noting that, "In time you will see that you do have a choice, you are just not ready to give it up yet." Bonnie, the 33-year-old bankruptcy coordinator for a student-loan service, said that the most helpful thing she learned online was how to "surf the urge to cut." She described this as:

It kind of comes in waves for me. I get these big tidal waves of emotion that rush through me and my first reaction for a long time was to cut, to make it stop. But 
now, if it's sadness, cry, if I'm angry, scream, if I'm ashamed, accept it. It's more about being mindful about whatever's happening to my body or my mind or my emotions at the time. But if I surf that urge, let it happen, it always passes. And that's actually been the most helpful for me.

\section{defining their behavior as chosen rather than uncontrollable was empowering.} The selected model especially differed from the other perspectives in arguing against the notion that self-injury was a bad thing; instead, proponents saw it as something helpful, at least for the present. A poster from Australia suggested that people selfinjured because they did not have the skills or motivations to use other means to cope. She saw it as a default because it worked, it was quick, and she considered it unnecessary for people to struggle with uncomfortable feelings. Jimmy, the Alaskan college student, went beyond that, arguing that cutting wasn't a problem, and suggesting that it was the way he dealt with his problems. In order for him to stop, he would have to stop the things that caused it. Although he would rather not injure himself, he pronounced himself "content with it." A Canadian poster argued that this bad coping strategy was a more acceptable way of dealing with his problems than others available to him, at least for the present, so he considered it "harm reduction."

Finally, some people indicated that they liked their self-injury. One poster said she had been going over the ins and outs of her cutting with her therapist and had come to the conclusion that she simply liked to hurt herself. It wasn't just that she enjoyed the release of tension or putting the hurt on the outside where she could see and control it, but her therapist pointed out to her how relaxed, enthusiastic, and happy she looked when she was talking about cutting herself. She closed her remarks by wondering if she should really be using this site, a recovery-oriented venue, at all.

Self-injury sites, then, eased participants' fears and rejections, helping them deflect the most severe stigmas they encountered in the world, but at the same time it settled them into communities that accepted their behavior to such a degree that it could make it easier to overlook its deviance and dysfunctionality.

\section{Effect of Cyberworld on Self-Injury}

How, then, does cyber group membership affect participants' self-injury: does this help them desist or draw them into continuing or increasing this behavior?

\section{Reinforcing}

51 Many of the sites, especially the early ones, were highly triggering, increasing members' likelihood of self-injuring. In other studies of the influence of the Internet on self-injury, Murray and Fox (2006) found that $7 \%$ of those queried reported an increase in the behavior, and Johnson, Zastawny and Kulpa (2010) noted an increase of $13.1 \%$ in the 67 people they surveyed online. When people posted their injury pictures, egged each other on, and even wrote about their blood dripping on the keyboard, participants considered this supportive of self-injuring. Even as late as this writing, sites still existed for posting photos that could be accessed by non-members. When people posted these with captions such as "my recent cutting," it reinforced people's urges to cut. Jimmy, from Alaska, said that "On [pro-SI site] I almost found it becoming competitive. I mean, 
when you are doing pictures you're looking, and you say 'Oh my god he's got the, the control to do that to himself. I wonder if I can?"' Darcy, the 19-year-old college student, compared self-injury Websites to commercials:

The more you're exposed to anything the more you do it. Like watching commercials, their goal is to make you do things, and you're trying to quit smoking and you're watching commercials and you're like "hmm, cigarettes." I think the exposure has that effect inherently. Don't think about a pink elephant, whatever you do.... Okay.

The sites that most supported self-injury were the pro-SI sites. Erica, who slammed her hand in the door, noted that she liked going to these sites when she was happy about her injuring. She read people talking about their injuries, how to keep them clean, how to manage their cuts so they didn't go too deep, and how to deal with drugs and therapists. Her view of these kinds of sites was that, "I see nothing wrong with it; it's what I would say too."

Finally, having self-injuring friends reinforced self-injury. Cody posted that, "When you have a group of people who cut and no one else, it's not very good." Gwen, the 20-yearold college student, suggested that, "You keep on doing it because that's what's expected in that group and it just gets worse because there's no outside force preventing you from doing that, I guess." Hannah, a 19-year-old college student who had spent a month in a specialized self-injury clinic, talked about how she saw people encouraging each other to injure in some of the sites:

They probably just egg each other on. Be like, "Oh I did this last night and I lost this much blood." And then someone would be like "Oh what are you talking about? I passed out last night from losing so much blood. You're a pussy!" and I feel like they just egg each other on, I don't know. Then there's the other one where they understand the problem, and they love that they have Internet friends who do the same things as they do and they can confide in them all of the horrible, horrible things that they do to themselves. That's more of one of the groups where they would just egg each other on and that can be good to have people who understand but that's also detrimental in the long run.

Self-injury cyber subcultures may also reinforce members' acts by sharing techniques and motives, and by normalizing and encouraging these ${ }^{12}$.

\section{Quitting}

Self-injury was more often reduced as the result of cyber-group membership. Murray and Fox (2006) found that $37 \%$ of those they queried had decreased their injuring, and Johnson, Zastawny and Kulpa (2010) noted a reduction of 55.8\%. Our research suggests that many of the people with whom self-injurers formed relationships offered helpful suggestions and support for recovery. When people felt the urge to injure, they sometimes went to the groups, boards, or chat rooms to distract themselves. Any time they spent there talking was time that they were not cutting or burning. People offered them helpful suggestions, from the shallowest ones to deep assistance for their cyberrevealed selves. People supported each other, as in solid world support groups, encouraging and congratulating individuals who passed significant markers in their desistance, such as yearly anniversaries. One person posted online:

I am happy to report that in 3 weeks it will be officially 1 year since I last self injured! Gah! This is HUGE 4 me! Just wanted to tell you all this, I wouldnt be here if not 4 you guys. *tear* 
Thanks!

Live life like a rock, strong and grounded!

Other reasons given were people realizing they were not alone but had community, the benefits they experienced of communicating with others who self-injured, the way the sites changed their thinking about self-injury, the help they got from others there in filling their emotional needs, and the overall support they got online (Johnson, Zastawny \& Kulpa, 2010).

57 Finally, when people slipped up and reverted, their online friends told them to start fresh, to take it one day at a time. One day was good; one week was good; one month was better. They all knew that healing was about ups and downs. They offered relief from the isolation and loneliness people faced in their moments of inner turmoil and feelings of addiction. Jessie, a 22-year-old living in Germany and working with a special needs child wrote: "When you find a safe board where there's not that many triggers it can actually be a really positive thing. It can be a supportive environment that actually helps you to stop or supports you when you're trying to stop."

\section{Mixed Effects}

In addition, many of these cyber contacts had mixed effects, sometimes triggering, sometimes helping, and sometimes having a combination or no effect. Johnson, Zastawny and Kulpa (2010) found that $31.1 \%$ reported no change in their self-injury as the result of their Internet participation, while Murray and Fox (2006) noted that of the $55.8 \%$ who indicated decreased self-injury, $14.8 \%$ had increased the behavior initially but reduced it over time. Erica noted that people made their own choices about how self-injury sites affected them. "You can go to that site and it will help you to cut because you see it and want to do it. Or you can go to that site and help you not do it. I think it's like whatever you're feeling, whatever you're going to that site for." The effect of a given site also depended on people's stage in their self-injury careers, whether they wanted the support to continue or the support to stop. Bonnie, the bankruptcy coordinator, reflected on this: "I think there's good and bad, and at one time I needed a pro-cutting and now I don't, and I don't look for it. So I think that depending on the stage that people are in they need certain things."

The relationships that self-injurers formed in these groups and sites were thus layered and complex, ephemeral and transitory while at the same time deep and meaningful. People treated their cyber friends differently, depending on their current needs and strengths. For some, this pulled them away from relationships in the solid world, but for many more, it supplemented these and helped them either bridge from a difficult period to one where they felt better or helped them move themselves through these stages. People got out of their cyber relationships and support groups what they invested there, and usually found people whose interests and goals mirrored their own. As such, these could have rather different effects on their solid world lives and behavior.

\section{Conclusion}

The cyber world offers people who are dispossessed by mainstream society a reservoir of hiding places where they can form their own cultures and communities, even though 
normative standards and assumptions frame these. These self-injury subcultures are back places, where people of similar preferences are freed from the need to conceal their deviance, openly seeking out one another for support and advice. The various philosophies framing these groups mean that people who are loners in the solid world can discover a range of communities available to them on the Internet, even dropping out of some groups and joining others as their self-injury careers evolve and progress.

61 As this research shows, the Internet has changed self-injury, re-casting it from an individualistic to a more collective context. Cyber self-injurers form online support groups that in some ways resemble and in other ways can be distinguished from their solid world counterparts. They are also the only collective venue for highly stigmatized deviance, around which face-to-face support groups do not form.

There are two significant impacts of this shift from a loner to a group environment. First, the Internet offers a community within which self-injurers may normalize their behavior. People who seek online community forge a wide range of cyber supporters who benefit them by being always available, portable, disposable, compartmentalized, intimate, and composed of peers. These features make cyber colleagues more valuable to them, in some ways, than friends in the solid world. The unwavering support and acceptance they find in cyberspace may free individuals from the worst conceptions of themselves, dispel absurd myths and beliefs they encounter in the solid world, and help them re-define their deviance from new perspectives.

Secondly, the collective organization of self-injurers may help advance the moral passage (Gusfield, 1967) of the behavior. This refers to the process by which designations shift, with certain attitudes, behaviors, or conditions moving from the realm of one moral status to another. To the extent that self-injurious individuals reject some of the more extreme definitions of their behavior as sinful, suicidal, or dangerous, they may shift the public recognition of their behavior, gaining greater public acceptance and reducing the social sanctions and stigma associated with their practice. In numbers, they gain the voice and social power to advance this alternate view of themselves and their acts, challenging that perpetrated by the media. And in eschewing the sick role, they further empower themselves. They cast off the dominance of the psycho-medical community and elevate themselves as the agentic experts capable of assessing the short- and long-term costs and benefits of their behavior.

Online self-injury communities thus display both the expressive and instrumental dimensions of collective stigma management groups conceptualized by Lyman (1970). They aid members expressively, offering them a safe forum for escaping the judgmentalism of others, providing a space for the collective diffusion of important information, replacing the norms and values of the dominant outside community with those of their own subculture, and giving them social interaction and community. Instrumentally, they enable members to forge new shared interpretations and definitions of their behavior that they can then take to the solid world, challenging the view of themselves and their acts as sick, weak, and deviant.

Finally, cyber-communities of self-injury have changed markedly over the first decade of the twenty-first century, with unfettered, unmonitored sites that encouraged the behavior gradually replaced, largely, by more monitored sites that fostered recovery. They can also be seen to have different effects on people depending on their stage in their deviant careers, with those at early, ascending phases embracing the behavior and those more ready to seek recovery able to use the group to assist their desistance. 
Yet these sites are still evolving, as is the social definition of the behavior, and its evolving prevalence and moral passage will also be affected by other factors such as the widespread diffusion of the practice beyond its early, initial population and the even broader awareness of its existence and nature.

\section{BIBLIOGRAPHY}

ALDRIDGE David \& ROSSITER Jacqueline (1984). “A Strategic Assessment of Deliberate Self-Harm“, Journal of Family Therapy, 6, pp. 113-29.

ANDOVER Margaret S., PEPPER Carolyn M., RYABCHENKO Karen A., ORRICO Elizabeth G. \& GIBB Brandon E. (2005). "Self-mutilation and Symptoms of Depression, Anxiety, and Borderline Personality Disorder", Suicide and Life-Threatening Behavior, 35, pp. 581-91.

BECKER Howard S. (1963). Outsiders, New York, Free Press.

BECKER Howard S. \& GEER Blanche (1969). "Participant Observation and Interviewing: A Comparison", in George J. McCall \& John L. Simmons (eds.), Issues in Participant Observation, Reading MA, Addison-Wesley, pp. 322-331.

BOWEN Arabella C.L. \& JoHN Alexandra M.H. (2001). “Gender Differences in Presentation and Conceptualization of Adolescent Self-injurious Behaviour: Implications for Therapeutic Practice", Counselling Psychology Quarterly, 14, pp. 357-79.

BROOKSBANK Donald J. (1985). "Suicide and Parasuicide in Childhood and Early Adolescence“, British Journal of Psychiatry, 146, pp. 459-63.

BRUMBERG Joan J. (1988). Fasting Girls: The Emergence of Anorexia Nervosa as a Modern Disease, Cambridge, Harvard University Press.

CHEN Shing-Ling, HALL Jon G. \& JOHnS Mark D. (eds.) (2003). Online Social Research: Methods, Issues, and Ethics, New York, Peter Lang.

COONS Philip M. \& MILSTEIN Victor (1990). “Self-mutilation Associated with Dissociative Disorders”, Dissociation, 3, pp. 81-87.

DESHOTEls Tina H. \& FORSYTH Craig J. (2007). “Postmodern Masculinities and the Eunuch”, Deviant Behavior, 28, pp. 201-18.

EGAN Jennifer (1997). “The Thin Red Line”, New York Times Magazine, July 27, pp. 21-35, 34, 40, $43-44,48$.

EYSENBACH Gunther, POWELL John, ENGLESAKIS Marina, RIZO Carlos \& STERN Anita (2004). “Health Related Virtual Communities and Electronic Support Groups: Systematic Review of the Effects of Online Peer to Peer Interactions", British Medical Journal, 328, pp. 1166-1170.

FAVARO Angela \& SANTONASTASO Paolo (1998). "Impulsive and Compulsive Self-Injurious Behavior in Bulimia Nervosa: Prevalence and Psychological Correlates”, The Journal of Nervous and Mental Diseases, 186, pp. 157-65. 
FAVAzzA Armando R. (1998). “The Coming of Age of Self-mutilation”, The Journal of Nervous and Mental Disease, 186, pp. 259-68.

FAVAzZA Armando R. (1989). "Why Patients Mutilate Themselves”, Hospital and Community Psychiatry, 40, pp. 137-45.

FAVAZZA Armando R. (1987). Bodies Under Siege: Self-mutilation and Body Modification in Culture and Psychiatry, Baltimore, Johns Hopkins University Press.

FAVAZZA Armando R. \& CONTERIo Karen (1989). "The Plight of Chronic Self-mutilators”, Community Mental Health Journal, 24, pp. 22-30.

FAVAZZA Armando R., DEROSEAR Lori \& CONTERIO Karen (1989). “Self-mutilation and Eating Disorders", Suicide and Life-Threatening Behavior, 19, pp. 352-61.

FORCE William R. (2005). “There are No Victims Here: Determination versus Disorder in ProAnorexia" Paper presented at the Couch-Stone Symposium of the Society for the Study for Symbolic Interaction, Boulder, CO, February.

GRATZ Kim L., CONRAD Sheree D. \& ROEMER Lizabeth (2002). "Risk Factors for Deliberate Self-harm among College Students", American Journal of Orthopsychiatry, 72, pp. 128-40.

GREENSPAN Gail C. \& SAMUEL Steven E. (1989). “Self-cutting After Rape”, American Journal of Psychiatry, 146, pp. 789-90.

GUSFIELD Joseph (1967). “Moral Passage: The Symbolic Process in Public Designations of Deviance”, Social Problems, 15, pp. 175-88.

Harwood Mark T. (2010). Self-help in mental health: a critical review. Luciano L'Abate, New York, Springer.

HERPERTZ Stephan (1995). "Self-injurious Behavior: Psychopathological and Nosological Characteristics in Subtypes of Self-injurers”, Acta Psychiatrica Scandinavica, 91, pp. 57-68. HODGSON Sarah (2004). "Cutting Through the Silence: A Sociological Construction of Self-Injury", Sociological Inquiry, 74, pp. 162-79.

JEFFREYS Sheila (2000). “'Body Art' and Social Status: Cutting, Tattooing and Piercing from a Feminist Perspective", Feminism \& Psychology, 10, pp. 409-29.

JOHNSON Genevieve Marie, ZASTAWNY Sylvia \& KULPA Anastasia (2010). "E-Message Boards for Those Who Self-Injure: Implications for E-Health", International Journal of Mental Health Addiction, 8, pp. 566-569.

JOINER Thomas E. (2005). Why People Die by Suicide, Cambridge, Harvard University Press. JONES Mike (2007). I Had to Say Something; The Art of Ted Haggard's Fall, New York, Seven Stories Press.

KALB Claudia (1998). “An Armful of Agony: Treatment Options for Self-mutilators”, Newsweek, November 9,82 .

KAPLAN Katy, SALZER Mark S., SOLOMON Phyllis, BRUSILOVSKIY Eugene, \& cousounis Pamela (2011). "Internet Peer Support for Individuals with Psychiatric disabilities: A Randomized Controlled Trial”, Social Science \& Medicine, 72, pp. 54-62.

KING Storm A. (1996). "Researching Internet Communities: Proposed Ethical Guidelines for the Reporting of Results", The Information Society, 12, pp. 119-128. 
KITSUSE John (1980). “Coming Out All Over: Deviants and the Politics of Social Problems”, Social Problems, 28, pp. 1-13.

KLONSKY David E., OLTMANNS Thomas F. \& TURKHEIMER Eric (2003). “Deliberate Self-Harm in a NonClinical Population”, American Journal of Psychiatry, 160, pp. 1501-1508.

KURTZ Linda F. (1997). Self-help and support groups: a handbook for practitioners, Thousand Oaks, Sage.

LEMERT Edwin (1967). Human Deviance, Social Problems, and Social Control, Englewood Cliffs (NJ), Prentice-Hall.

LENHART Amanda, MADDEn Marilyn \& HITLIN Paul (2005). “Teens and Technology: Youth are Leading the Transition to a Fully Wired and Mobile Nation", Retrieved February 7, 2007, http:// www.perInternet.org/pdfs/PIP_Teens_Tech_July2005web.pdf LYMAN Stanford (1970). The Asian in the West, Reno/Las Vegas, Western Studies Center, Desert Research Institute.

MANN Chris \& STEWART Fiona (2000). Internet Communication and Qualitative Reseach: A Handbook for Researching Online, London, Sage.

MCKENNA Katelyn Y.A. \& BARGH John A. (1998). “Coming Out in the Age of the Internet: Identity 'Demarginalization' through Virtual Group Participation”, Journal of Personality and Social Psychology, 75, pp. 681-94.

MILLER Frank \& BASHKIN Edmund (1974). “Depersonalization and Self-mutilation”, Psychoanalysis Quarterly, 43, pp. 638-49.

MOos Rudolph H., FINNEY John W., OUIMETTE Paige C. \& SUCHINSKY Richard T. (1993). “A Comparative Evaluation of Substance Abuse Treatment: I. Treatment Orientation, Amount of Care, and 1-Year Outcomes", Alcoholism: Clinical and Experiential Research, 23, pp. 529-536.

MOREY Leslie C. \& ZANARINI Mary C. (2000). “Borderline Personality: Traits and Disorder”, Journal of Abnormal Psychology, 109, pp. 733-37.

MURRAY Craig D. \& FOX Jezz (2006). “Do Internet Self-Harm Discussion Groups Alleviate or Exacerbate Self-Harming Behaviour?" Australian e-Journal for the Advancement of Mental Health, 5, Retrieved January 20, 2007, www.ausienet.com/journal/vol5isse/murray.pdf

NOCK Matthew K. \& PRINSTEIN Mitchell J. (2005). “Contextual Features and Behavioral Functions of Self-mutilation among Adolescents”, Journal of Abnormal Psychology, 114, pp. 140-46.

NOCK Matthew K. \& PRINSTEIN Mitchell J. (2004). “A Functional Approach to the Assessment of Selfmutilative Behavior”, Journal of Counseling and Clinical Psychology, 72, pp. 885-90.

PATTISON Mansell E. \& KAHAN Joel (1983). “The Deliberate Self-harm Syndrome”, American Journal of Psychiatry, 140, pp. 867-72.

PEW (2008). Pew Internet \& American Life Project Tracking Survey, http://www.pewinternet.org/ Statis-Pages/Trend-Data/Whos-Online.aspx.

PFOHL Bruce (1991). “Histrionic Personality Disorder”, Journal of Personality Disorders, 5, pp. 150-65.

PITMAN Roger K. (1990). “Self-mutilation in Combat Related Post-traumatic Stress Disorder”, American Journal of Psychiatry, 147, pp. 123-24.

RIESSMAN Frank (1965). “The ‘Helper-Therapy’ Principle”, Social Work, 10, pp. 27-32. 
RODHAM Karen, GAVIN Jeff \& MILES Meriel (2007). “I Hear, I Listen and I Care: A Qualitative Investigation into the Function of a Self-Harm Message Board", Suicide and Life-Threatening Behavior, 37, pp. 422-30.

ROSS Shana \& HEATH Nancy (2002). "A Study of the Frequency of Self-Mutilation in a Community Sample of Adolescents", Journal of Youth and Adolescence, 31, pp. 67-77.

SCHAFFER Charles B., CARROLL Jacqueline \& ABRAMOWITZ Stephen I. (1982). "Self-mutilation and the Borderline Personality", Journal of Nervous Mental Disorders, 170, pp. 468-73.

SHARKEY Valerie (2003). “Self-Wounding: A Literature Review”, Mental Health Practice, 6, pp. 35-37. SHEARER Steven L. (1994). "Phenomenology of Self-Injury among Inpatient Women with Borderline Personality Disorder”, Journal of Nervous Mental Disorders, 182, pp. 524-26.

SOLOMON Yvette \& FARRAND Julie (1996). “Why Don't You Do it Properly?: Young Women who Selfinjure", Journal of Adolescence, 19, pp. 111-19.

STRONG Marilee (1998). A Bright Red Scream: Self-Mutilation and the Language of Pain, New York, Viking Penguin.

SUYEMOTO Karen L. \& MACDONALD Marian L. (1995). “Self-cutting in Female Adolescents”, Psychotherapy, 32, pp. 162-71.

TANTAMN Digby \& WHITTAKER James K. (1992). “Personality Disorder and Self-wounding”, British Journal of Psychiatry, 161, pp. 451-64.

THOMPSONN William E. \& HICKEY Joseph V. (1998, November 9). “What the Cutters Feel”, Time, p. 93. TIERNEYN Stephanie (2008). “Creating Communities in Cyberspace: Pro-Anorexia Web Sites and Social Capital”, Journal of Psychiatric \& Mental Health Nursing, 15, pp. 340-43.

VAN DER KOLK Bessel A., PERRY Christopher J. \& HERMAN Judith Lewis (1991). “Childhood Origins of Self-destructive Behavior”, American Journal of Psychiatry, 148, pp. 1665-71.

VANNINI Phillip, MCMAHON Martha \& MCCRIGHT Aaron (2005). "Not a Pretty Site: Gendered Bodies, Endangered Selves, and Eating (Dis)orders", Paper presented at the Couch-Stone Symposium of the Society for the Study of Symbolic Interaction, Boulder, CO, February.

VIRKKUNEN Matti (1976). "Self-mutilation in Antisocial Personality Disorder", Acta Psychiatric Scandanavia, 54, pp. 347-52.

WAISMAN Morris (1965). "Pickers, Pluckers and Impostors: A Panorama of Cutaneous Selfmutilation", Postgraduate Medicine, 38, pp. 620-30.

WASKUL Dennis (ed.) (2004). Net.seXXX: Readings on Sex, Pornography, and the Internet, New York, Peter Lang.

. (2003). Self-games and Body-play: Personhood in Online Chat and Cybersex, New York, Peter

Lang.

WASKUL Dennis \& DOUGLASS Mark (1996). “Considering the Electronic Participant: Some Polemical Observations on the Ethics of On-line Research", The Information Society, 12, pp. 129-139.

WHITLOCK Janis, ECKENRODE John \& SILVERMAN Daniel (2006). “Self-injurious Behaviors in a College Population." Pediatrics, 117, pp. 1939-48.

WHITLOCK Janis, LADER Wendy \& CONTERIO Karen (2006). “The Internet and Self-Injury: What Psychotherapists Should Know”, Journal of Clinical Psychology, 63(11), pp. 1135-1143. 
WHITLOCK Janis, POWERS Jane L. \& ECKENRODE John (2006). “The Virtual Cutting Edge: The Internet and Adolescent Self-Injury”, Developmental Psychology, 40, pp. 7-17.

\section{NOTES}

1. Terms that have been used include self-harm or deliberate self-harm syndrome (Aldridge \& Rossiter, 1984; Grantz, Conrad \& Roemer, 2002; Pattison \& Kahan, 1983), self-mutilation (Favazza, 1989, 1998; Favazza \& Conterio, 1989; Nock \& Prinstein, 2004, 2005; Ross \& Heath, 2002; Strong, 1998; Waisman, 1965), self-destruction (van der Kolk, Perry \& Herman, 1991), self-cutting (Suyemoto \& MacDonald, 1995), self-injurious behavior (Bowen \& John, 2001; Herpertz, 1995; Shearer, 1994), self-wounding (Brooksbank, 1985; Sharkey, 2003; Tantum \& Whittaker, 1992), and self-injury (Hodgson, 2004; Solomon \& Farrand, 1996).

2. Andover et al., 2005; Klonsky, Oltmanns \& Turkheimer, 2003.

3. Brumberg, 1988; Favaro \& Santonastaso, 1998; Favazza, 1987; Favazza, DeRosear \& Conterio, 1989; Favazza, 1998; Whitlock, Eckenrode \& Silverman, 2006.

4. Andover et al., 2005; Bowen \& John, 2001; Coons \& Milstein, 1990; Favazza, DeRosear \& Conterio, 1989; Greenspan \& Samuel, 1989; Klonsky, Oltmanns \& Turkheimer, 2003; Miller \& Bashkin, 1974; Morey \& Zanarini, 2000; Pfohl, 1991; Pitman, 1990; Ross \& Heath, 2002; Schaffer, Carroll \& Abramowitz, 1982; Virkkunen, 1976.

5. Several celebrities publically admitted that they self-injured, among them Fiona Apple, Drew Barrymore, Brody Dale, Johnny Depp, Richey Edwards, Colin Farrell, Kelly Holmes, Angelina Jolie, Courtney Love, Marilyn Manson, Shirley Manson, Princess Diana, Christina Ricci, Amy Studt, Sid Vicious, Amy Winehouse, and Elizabeth Wurtzel (see http://self-injury.net/ or www.selfinjury.net/doyousi/famous.htma).

6. Nine Inch Nails' song, "Hurt," “Crawling” by Linkin Park, and "Last Resort" by Papa Roach, all addressed self-injury, and several punk rock musicians featured showy onstage imitations of cutting such as Marilyn Manson, Iggy Pop, and GG Allin.

7. The New York Times ran a cover article in its magazine section in 1997 on self-injury that grabbed a lot of attention (see Egan, 1997), and Newsweek and Time ran stories on it in 1998 (see Kalb, 1998; Thompson \& Hickey, 1998). Some popular treatments that came to public attention at around this time included films such as "Girl Interrupted", "Nightmare on Elm Street III," and "Secretary," as well as television shows with episodes on cutting such as "ER", and documentary treatments on The Learning Channel.

8. For purposes of clarity we more commonly refer to the face-to-face world as the solid world, as opposed to the real world, since some people we encountered during this research felt that the cyber world was more real than the physical, embodied world.

9. Institutional Review Board, or ethics committee.

10. To retain the integrity of the postings, we have not altered or corrected the spelling, grammar, of any other features of messages or emails we retrieved from the Internet.

11. See Tierney, 2008; Force, 2005; Vannini, McMahon \& McCright, 2005 for a discussion of Pro-ED communities and movements. For Websites dedicated to the Pro-ED movement, see: http:// www.eating-disorder.org/prosites and http://www.anad.org/proanorexia.htm.

12. Rodham, Gavin \& Miles, 2007; Whitlock, Powers \& Eckenrode, 2006. 


\section{ABSTRACTS}

Previous models of therapeutic treatment for self-injury have been focused on individualistic psycho-medical approaches that isolate and stigmatize people who cut, burn, and otherwise selfharm. The rise of cyber communities of self-injury, beginning in the early 2000s but evolving dramatically over the first decade of the twenty-first century, has offered a diversity of groups that individuals can join, cycling through different ones as their movement through their career of self-injury evolves. These groups offer a significantly different set of norms and values relating to self-injury, engaging in some combination of defining it, normalizing it, supporting it, and offering a range of techniques for combatting it. In this article we discuss the various ways different people participate in these cyber communities, their relationships between the cyber and face-to-face worlds, and the effects of the Internet on self-injury. We conclude by discussing the instrumental and expressive effects of cyber self-injury support groups, and the way these groups function to normalize the behavior and foster its moral passage.

Les précédents modèles de traitement thérapeutique des pratiques d'automutilation étaient basés sur des approches psycho-médicales individualistes, qui tendaient à isoler et à stigmatiser les personnes pratiquant diverses blessures auto-infligées comme les coupures ou les brûlures. Dès le début des années 2000, l'apparition de communautés en ligne consacrées à cette pratique, qui se développent de façon spectaculaire au cours de la première décennie du XXIe siècle, présente aux individus une diversité de groupes qu'ils peuvent rejoindre et dans lesquels ils peuvent évoluer au cours de leurs carrières d'automutilation. Ces groupes proposent à leurs membres un ensemble de normes et de valeurs alternatives concernant l'automutilation, ce qui leur permet de définir et de «normaliser » leur pratique, d'obtenir du soutien, ou encore d'avoir accès à une gamme de techniques pour lutter contre elle. Dans cet article, nous examinons les différentes manières dont les personnes participent à ces communautés en ligne, les rapports entre mondes en ligne et face-à-face, et les effets que produit Internet sur l'automutilation. Nous concluons par une discussion sur les effets instrumentaux et expressifs des groupes de soutien à destination des personnes qui s'automutilent et la façon dont ces groupes contribuent à « normaliser » ce comportement et à favoriser un moral passage au sens de Gusfield.

\section{INDEX}

Mots-clés: automutilation, déviance, communautés thérapeutiques, forums, santé mentale Keywords: self-injury, deviance, therapeutic communities, forums, mental health

\section{AUTHORS}

\section{PATRICIA A. ADLER}

University of Colorado, Department of Sociology

\section{PETER ADLER}

University of Denver, Department of Sociology \& Criminology 